DOI 10.31558/2307-2318.2020.1.16

УДК 338.2: 620.95(075.8)

Сакун Л.М., к.е.н., доцент, доцент кафедри менеджменту Кременчуцького національного університету імені Михайла Остроградського

Різніченко Л.В., викладач кафедри менеджменту Кременчуцького національного університету імені Михайла Остроградського

Вєлькін Б.О., студент Кременчуцького національного університету імені Михайла Остроградського

\title{
ПЕРСПЕКТИВИ РОЗВИТКУ РИНКУ БІОГАЗУ В УКРАЇНІ ТА ЗА КОРДОНОМ
}

Енергозабезпечення населення і глобальна екологічна криза змушує країни світу впроваджувати і застосовувати нові альтернативні засоби виробітку енергії. Враховуючи майже невичерпні сировинні ресурси, все більше уваги держав привертають методи видобування і переробки біогазу. Сприятливі зміни в закононодавстві ще більше стимулюють інвесторів вкладати кошти у будівництво біогазових установок.

Основним методом вирішення проблеми виступає впровадження ефективних заходів переробки відходів з метою отримання позитивного економічного й екологічного ефекту від виробництва біогазу.

Метою роботи є вдосконалення методів утилізації відходів шляхом видобування 3 них біогазу з подальшою генерацією енергії та покращення екологічної ситуації на регіональному рівні. У науковій статті розроблено систему оцінки ефективності впровадження біогазових установок на регіональному рівні. Проаналізовано процеси утворення та поводження з різними видами відходів, які можуть використовуватися у якості сировини для біогазу, в Україні. Оцінено переваги і недоліки використання біогазових технологій. Зроблено порівняльний аналіз європейського та вітчизняного ринків біогазу. Розраховано економічну ефективність від будівництва та експлуатації біогазової установки в межах енергетичного кооперативу на території Кременчуцького району Полтавської області.

Ключові слова: ринок біогазу, біогазові установки, енергетичний кооператив, інвестиції у відновлювані види енергії, зелений тариф.

Рис. - 5., Табл. - 2, Літ. - 16

Сакун Л.Н., Ризниченко Л.В., Велькин Б.О. ПЕРСПЕКТИВЫ РАЗВИТИЯ РЫНКА БИОГАЗА В УКРАИНЕ И ЗА РУБЕЖОМ

Энергообеспечение населения и глобальный экологический кризис заставляет страны мира внедрять и применять новые альтернативные средства выработки энергии. Учитывая почти неисчерпаемые сырьевые ресурсы, все больше внимания государств привлекают методы добычи и переработки биогаза. Благоприятные изменения в закононодательстве еще больше стимулируют инвесторов вкладывать средства в строительство биогазовых установок.

Основным методом решения проблемы выступает внедрение эффективных мер переработки отходов с целью получения положительного экономического и экологического эффекта от производства биогаза.

Целью работы является совершенствование методов утилизации отходов путем извлечения из них биогаза с последующей генерацией энергии и улучшение экологической ситуации на региональном уровне. В научной статье разработана система оценки эффективности внедрения биогазовых установок на региональном уровне.

Проанализированы процессы образования и обращения с различными видами отходов, которые могут использоваться в качестве сырья для биогаза в Украине. Оценены 
преимущества и недостатки использования биогазовых технологий. Сделан сравнительный анализ европейского и отечественного рынков биогаза.

Рассчитана экономическая эффективность от строительства и эксплуатации биогазовой установки в пределах энергетического кооператива на территории Кременчугского района Полтавской области.

Усовершенствованы методы утилизации отходов путем извлечения из них биогаза с последующей генерацией энергии на региональном уровне и улучшение экологической ситуации.

Ключевые слова: рынок биогаза, биогазовые установки, энергетический кооператив, инвестиции в возобновляемые виды энергии, зеленый тариф.

\section{Sakun L., Riznichenko L., Vielkin B. PROSPECTS OF BIOGAS MARKET DEVELOPMENT IN UKRAINE AND ABROAD}

The energy supply of the population and the global environmental issues are forcing countries to come up with new alternative methods of energy production. Taking into account almost infinite raw materials, the methods of biogas production and processing are becoming more and more relevant for many countries. Favorable changes in the legislation is another factor that encourage investors to set up biogas plants.

The main method of solving the problem is the introduction of efficient waste management to gain a positive economic and environmental impact of biogas production.

The aim of the work is to improve the methods of waste recycling by extracting biogas with further generation of energy in terms of improving the environmental situation.

The scientific article elaborates a system for evaluating the efficiency of implementation of biogas plants at the regional level. The process of formation and management of different types of waste that can be used as biogas feedstock in Ukraine are analyzed. The advantages and disadvantages of using biogas technologies were evaluated.

A comparison of the European and domestic biogas markets is made.

The economic effect from the construction and exploitation of the biogas plant within the energy cooperative on the territory of the Kremenchug district of Poltava region is estimated.

Key words: biogas market, biogas plants, energy cooperative, investments in renewable energy, green tariff.

Постановка проблеми та іiї актуальність. Енергозабезпечення населення i глобальна екологічна криза змушує країни світу впроваджувати і застосовувати нові альтернативні засоби виробітку енергії. Постає необхідність пошуку інноваційних джерел енергії, які не завдають шкоди довкіллю і мають значний економічний ефект. Виробництво біогазу є привабливою альтернативою з точки зору виробітку енергії. Враховуючи майже невичерпні сировинні ресурси все більше уваги держав привертають методи видобування i переробки біогазу. До того ж, цей вид палива $\epsilon$ багатофункціональним і може застосовуватися у різних сферах.

Будівництво біогазових установок - це крок до економіки замкненого циклу (циклічної економіки), спрямованої на впровадження відновлюваних джерел енергії, скорочення викидів парникових газів тощо. Дані чинники визначили вибір теми та зміст завдань наукової публікації, зумовили їх актуальність і практичне значення.

Аналіз останніх досліджень. Вирішенню проблем виробітку біогазу, видобутого 3 відходів, для енергозабезпечення присвячено праці як вітчизняних, так і зарубіжних 
вчених: Б. Едера, Х. Шульца [1], Ю. Матвєєва, Г. Гелетухи [2], М. А. Хажмурадова [3], Ю. Шафаренка [4], Г. М. Калетніка [5] та інших.

Разом $з$ цим недостатньо реалізується впровадження інноваційних технологій щодо зменшення негативного впливу на навколишнє середовище. Вимагають додаткової оптимізації методи переробки відходів з утворенням електроенергії на регіональному рівні, що вказує на необхідність проведення досліджень у цій сфері та розрахунку економічного й екологічного ефекту від утилізації відходів для видобутку біогазу в Україні та окремих регіонах.

Мета статті. Метою роботи є вдосконалення методів утилізації відходів шляхом видобування з них біогазу з подальшою генерацією енергії та покращення екологічної ситуації на регіональному рівні.

Виклад основновного матеріалу. Проблема ефективної переробки і утилізації відходів є однією з найгостріших у світі. Увага до питань раціонального поводження 3 відходами в Україні з боку як органів влади, так і наукових кіл в останні роки значно посилилась [1-6].

Вирішення проблеми можливе завдяки впровадженню ефективних заходів швидкої, безпечної переробки відходів і отриманню позитивного економічного й екологічного ефекту від утилізації та багаторазового використання сировини.

Утворення та поводження 3 різними видами відходів, які можуть використовуватися у якості сировини для біогазу в Україні, представлено на рисунку 1.

За період з 2014 по 2018 р.p. в Україні спостерігається стабільна тенденція до збільшення утворених побутових та подібних відходів (ППВ) на 1109,2 тис. т. [7, 8] Питома вага спалених з метою отримання енергії і утилізованих ППВ взагалі мізерна по відношенню до обсягів утворених ППВ (1,4\% у 2014 році та 1,87\% у 2018 році).

Все це вказує на величезні можливості використання відходів у якості сировини для генерації біогазу й енергії, і одночасно, суттєвого зменшення негативного впливу на навколишнє середовище.

Біогаз - це суміш газів (метану та вуглекислого газу), отримана з біомаси внаслідок анаеробного бродіння в спеціальних реакторах (метантанках), що використовується як паливо [1-3].

На прийняття рішення інвестором щодо вибору біогазових установок впливають наступні фактори: вид і властивості сировини, її доступні обсяги і логістика.

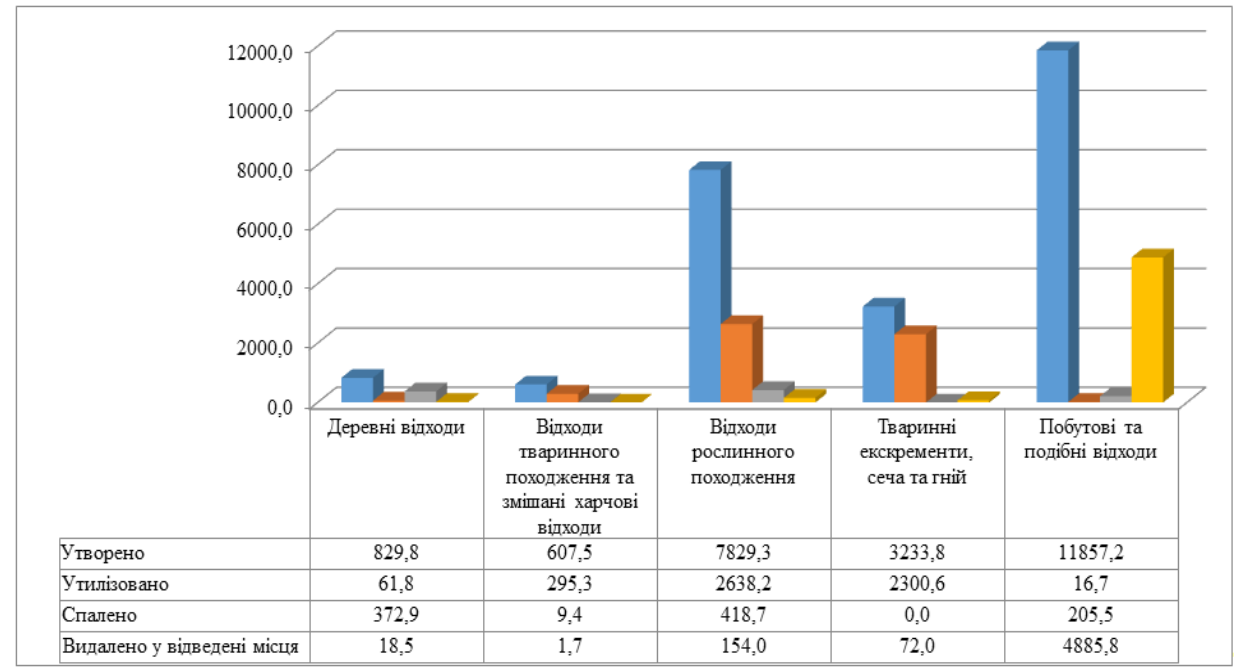

Рисунок 1 - Утворення та поводження з різними видами відходів, які можуть використовуватися у якості сировини для біогазу, у 2018 р. в Україні [7] 
На рис. 2 показано вихід біогазу при використанні різних видів сировини. При виборі біогазових установок ураховують, що вони можуть працювати на різних видах сировини одночасно і використовувати різні способи ії переробки залежно від вологості. Для підвищення ефективності виходу біогазу i скорочення терміну окупності обладнання застосовують спеціальні добавки (ензими).

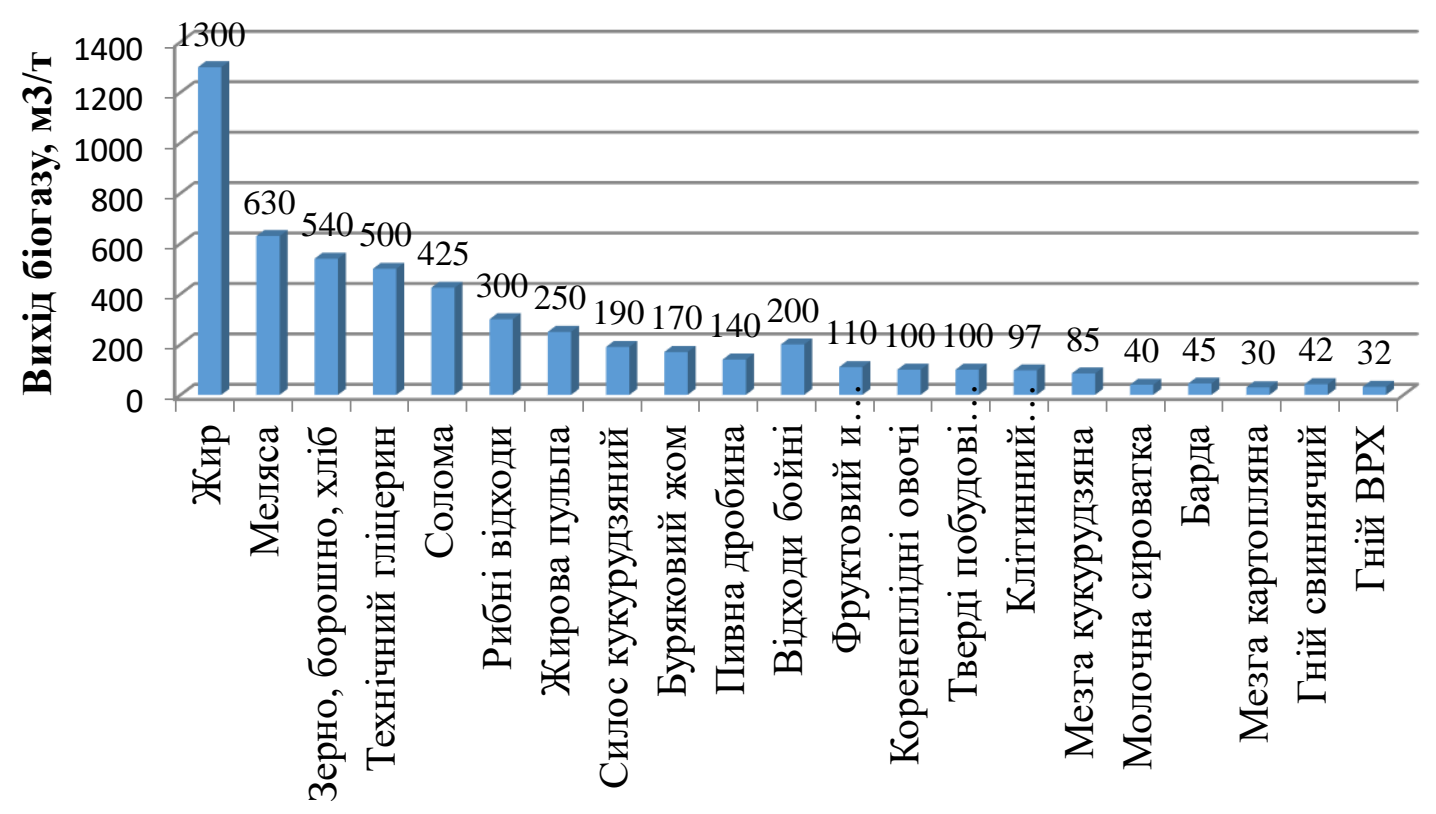

Види сировини

Рисунок 2 - Вихід біогазу з 1 тони сировини [2,5]

Переваги і недоліки використання біогазових технологій представлені на рис. 3.

Виробництво електроенергії і тепла із біогазу здійснюється на біогазових електростанціях і електростанціях на біомасі.

Обидва види електростанцій працюють на біомасі, різниця полягає лише у характеристиках сировини для біогазу і незначних змінах у технологічному процесі. При цьому, завдяки сучасним технологіям біогаз можна виробляти після попередньої підготовки практично з будь-якої органічної сировини.

Для біогазових електростанцій найбільш ефективними є наступні види сировини: відходи з ферм, сільськогосподарських підприємств (силос, жом, гній, послід і т.д.), стічних вод, побутові відходи зі сміттєзвалищ і полігонів.

Тобто та сировина, для якої характерна ферментація (мікробне розкладання та бродіння за допомогою бактерій) і здатність виділяти біогаз, який на 60-70\% складається 3 метану і на треть із $\mathrm{CO}_{2}$.

Прискорення процесу перетворення і ферментації сировини відбувається за рахунок іï підігріву в спеціальних реакторах, подальшого перемішування i акумулювання біогазу в резервуарах перед здійсненням процесу виробництва теплової та електричної енергії і, якщо треба, біометану після очищення біогазу від вуглекислого газу. На виході процесу виробництва біогазу може залишатися ферметована сировина (дігестат), яку можна застосовувати як екологічно чисте добриво. 


\section{Переваги}

Відновлюване джерело енергії (біомаса)

Високий потенціал виробництва біогазу з відходів АПК і полігонів ТПВ

Універсальність способів енергетичного використання біогазу (виробництво енергії, палива для автомобілів)

Стабільність виробництва електроенергії з біогазу протягом року

Конкурентоспроможне енергетичне використання орних земель у порівнянні з виробництвом рідких моторних палив (біоетанолу та біодизелю)

\section{Створення нових робочих місць}

Зниження негативного впливу на навколишнє середовище за рахунок переробки та знешкодження відходів і скорочення викидів парникових газів в атмосферу

Агротехнічний ефект (поліпшення структури грунтів, регенерація та підвищення їх родючості за рахунок внесення органічних добрив)

Використання «зелених» тарифів

\section{Недоліки}

Підвищення вивільнення окису азоту

Велика питома вага у біогазі домішок

(30-40 об.\% $\mathrm{CO}_{2}$ ), що потребує наявності очисних заводів або блоків

Висока потреба в субвенціях (дотаціях)

Низький виробничий потенціал $\mathrm{i}$ рентабельність біогазових установок

Зростання цін на продукти харчування (різке скорочення використання сільгоспкультур для виробництва біопалива)

Попередня підготовка окремих органічних відходів (соломи, деревини) шляхом ензиматичного або кислотного гідролізу

Процес метаногенезу є непрогнозованим і важко піддається регуляції

Рисунок 3 - Переваги і недоліки використання біогазових технологій $[2-4,13]$ 
Електростанції на біомасі зазвичай працюють на відходах деревообробки (брикети, пелети, гілки) та зернових культур (стебла, солома, луска насіння). Але навіть цю сировину можна застосовувати в біогазових реакторах за допомогою спеціальних технологій. Отже, принципова різниця біогазової електростанції від електростанції на біомасі полягає у виробленні побічних продуктів (добрив і біометана) на відміну від останньої, де відбувається повне спалювання сировини для отримання електрики і тепла. Біогаз, зібраний з полігонів твердих побутових відходів має високий вміст азоту, кисню, сполук сірки, хлору, силоксанів. У склад біогазу із відходів та сировини сільського господарства входить в основному сірководень та аміак.

Наявність кисню у біогазі з полігонів ТПВ сприяє корозії і біообростанням у газосховищах, що негативно впливає на подальше транспортування та утилізацію біогазу. Тому важливою задачею при виробництві біометану є максимальне скорочення потрапляння кисню у біогаз, що стає можливим завдяки різним способам попередньої очистки і контролю за потраплянням повітря у системи очистки біогазу на полігонах ТПВ. В умовах політичної та економічної кризи розвиток біоенергетики в Україні сприятиме значному зменшенню у використанні природного газу і частковому його заміщенню у секторі постачання теплової та електроенергії.

Здійснимо аналіз ринку біогазу в Україні та за кордоном з метою виявлення проблем і подальших перспектив у даній галузі.

Обсяги інвестицій в біогазові станції в Україні за період 2012-2019 рр. становлять близько 112 млн євро [8,10,11].

При цьому станом на 01.10.2019 p, 47 МВт (67 \%) електроенергії виробляється біогазовими електростанціями, що працюють на відходах АПК, а $23 \mathrm{MBT}$ - із біогазу з полігонів ТПВ (табл. 1). Розвиток ринку біогазу в Україні, зважаючи на високу інвестиційну вартість, відбувається в основному завдяки великим компаніям. В той час як у країнах Європи більш ніж 50\% фермерських господарств мають БГУ різної потужності завдяки програмам державної підтримки $[10,14]$. Так, у Німеччині кількість діючих на базі фермерських господарств біогазових станцій складає близько 10000. Здебільшого це установки малої потужності, а кількість великих біометанових заводів становить 194 [12,14].

Таблиця 1

Динаміка кількості біогазових установок і обсягу вироблясмої електроенергії в Україні за період 2012-2019 рр. [11]

\begin{tabular}{|c|c|c|c|c|c|c|}
\hline & \multicolumn{3}{|c|}{ Кількість біогазових установок, од. } & \multicolumn{3}{|c|}{$\begin{array}{c}\text { Потужність біогазових } \\
\text { установок, МВт }\end{array}$} \\
\cline { 2 - 7 } Роки & $\begin{array}{c}\text { біогаз із } \\
\text { відходів та } \\
\text { сировини } \\
\text { АПК }\end{array}$ & $\begin{array}{c}\text { біогаз із } \\
\text { полігонів } \\
\text { ТПВ }\end{array}$ & всього & $\begin{array}{c}\text { біогаз із } \\
\text { відходів та } \\
\text { сировини } \\
\text { АПК }\end{array}$ & $\begin{array}{c}\text { біогаз із } \\
\text { полігонів } \\
\text { ТПВ }\end{array}$ & всього \\
\hline 2012 & 0 & 7 & 7 & 0 & 7 & 7 \\
\hline 2013 & 2 & 7 & 9 & 7 & 7 & 14 \\
\hline 2014 & 3 & 7 & 10 & 8 & 7 & 15 \\
\hline 2015 & 5 & 7 & 12 & 11 & 7 & 18 \\
\hline 2016 & 6 & 7 & 13 & 14 & 7 & 21 \\
\hline 2017 & 9 & 12 & 21 & 23 & 11 & 34 \\
\hline 2018 & 13 & 20 & 33 & 28 & 18 & 46 \\
\hline 2019 & 20 & 25 & 45 & 47 & 23 & 70 \\
\hline
\end{tabular}


Частка біогазу у Данії на 2017 рік у постачанні загальної енергії становила 22\%. А це вже майже ті обсяги, коли можна розглядати питання про перспективу повного заміщення природного газу біометаном (очищеним біогазом).

Порівняння статистичних даних по Україні (табл. 1) з даними по Німеччині (табл. 2) показало суттєву відсталість вітчизняного ринку біогазу від європейського лідера.

Таблиця 2

Динаміка кількості біогазових установок і обсягу вироблясмої електроенергії у Німеччині за період 2004-2019 рр. [12]

\begin{tabular}{|c|c|c|}
\hline Роки & $\begin{array}{c}\text { Кількість біогазових установок, } \\
\text { од. }\end{array}$ & $\begin{array}{c}\text { Обсяг виробляємої } \\
\text { електроенергї̈, МВт }\end{array}$ \\
\hline 2004 & 2050 & 390 \\
\hline 2005 & 2680 & 650 \\
\hline 2006 & 3500 & 1100 \\
\hline 2007 & 3711 & 1271 \\
\hline 2008 & 3891 & 1377 \\
\hline 2009 & 5205 & 1893 \\
\hline 2010 & 6311 & 2291 \\
\hline 2011 & 7838 & 3097 \\
\hline 2012 & 8292 & 3352 \\
\hline 2013 & 8649 & 3637 \\
\hline 2014 & 8746 & 3906 \\
\hline 2015 & 9014 & 4018 \\
\hline 2016 & 9209 & 4237 \\
\hline 2017 & 9331 & 4550 \\
\hline 2018 & 9444 & 4953 \\
\hline 2019 & 9523 & 5228 \\
\hline
\end{tabular}

При цьому Україна має значний потенціал за рахунок високів темпів розвитку сільського господарства як основного постачальника біоенергетичної сировини, а також завдяки низькій насиченості ринку (1,3\% від обсягу виробляємої біоенергії Німеччини). Сьогоднішня ситуація вітчизняного ринку біогазу нагадує 2000 -і роки в Німеччині (табл. 2), напередодні 10-річного піку будівництва біогазових установок і вироблення біогазової енергії. На активність зростання кількості біогазових станцій в Європі вплинула, перш за все, державна політика щодо покращення охорони навколишнього середовища та боротьби 3 викидами парникових газів внаслідок низької переробки побутових і промислових відходів. Метан (компонент біогазу), який утворюється при розкладанні відходів, без переробки забруднює атмосферне повітря і тим самим ускладнює екологічну ситуацію. Тому європейські країни підтримують і стимулюють компанії, що переробляють побутові та інші органічні відходи, займаються виробництвом біогазу з подальшим отриманням електроенергії, тепла і біоетанолу, за рахунок «зелених» тарифів і пільгових відсоткових ставок по кредитах для таких проектів [15].

Розвиток біоенергетичної індустрії привів до вирощування енергетичних культур, які використовуються як сировина для виробництва біогазу. Лише у Німеччині під такі культури відводиться більше 1,2 млн. га землі [12]. 
Після очищення біогазу від домішок, отриманий біометан через газорозподільчу мережу подається на електростанції для подальшого виробництва енергії або використовується в якості палива для автомобілів.

При розвитку вітчизняного ринку біогазу доцільно урахувати досвід однієї із європейських країн Литви $[4,14]$, а саме наступні пропозиції:

1. Литовським регулятором було забезпечено додаткову до звичайної рентабельність у розмірі 6\% (загальна рентабельність складала $11 \%$ ) для установок виробництва енергії з біомаси тривалістю 16 років. При інфляції в $2 \%$ даний захід сприяв економічному стимулюванню інвесторів вкладати кошти в біогазові установки.

2. 32012 p. у Литві працює біопаливна біржа Baltpool. Питома вага біомаси, купленої на біржі, збільшилась з 1\% у 2013 р. до 95\% у 2017 р. Створення біопаливної біржі сприяло підвищенню прозорості та конкурентоспроможності при закупівлі біомаси як сировини для біогазу (спостерігалося зниження вартості біомаси у 2015 р. на 40\% відносно з 2012 р.)

3. Демонополізація генерації теплової енергії в централізованих мережах теплопостачання і можливість підключення інших виробників тепла до теплових систем, що сприяло забезпеченню споживачів дешевою енергією i теплом із біомаси i зменшенню тарифів. Тобто, при виграші аукціону на біопаливній біржі незалежним виробникам теплової енергії надавалась можливість гарантованого продажу тепла в централізовану систему.

На 2016 рік за статистикою Європейської біогазової асоціації кількість біогазових комплексів у європейських країнах становила 17662 одиниць, 3 них 497 займалися очищенням біогазу та виробленням біометану (у 2011 році лише 187). Як зазначають експерти Європейської біогазової асоціації, в найближчі десять років буде спостерігатися стрімке зростання секторів біогазу та біометану, а у перспективі питома вага біометану у європейському виробництві газу складатиме 33-40\%. При цьому члени Свропейської біогазової асоціації вважають достатньо високим потенціал виробництва біогазу і біометану в Україні. Недаремно, у 2019 році Україна зайняла 8-у позицію серед 100 країн світу, які розвиваються, за привабливістю інвестицій у відновлювані види енергії (BВЕ) [10], що на 55 місць вище, ніж у 2018 році (рис. 4).

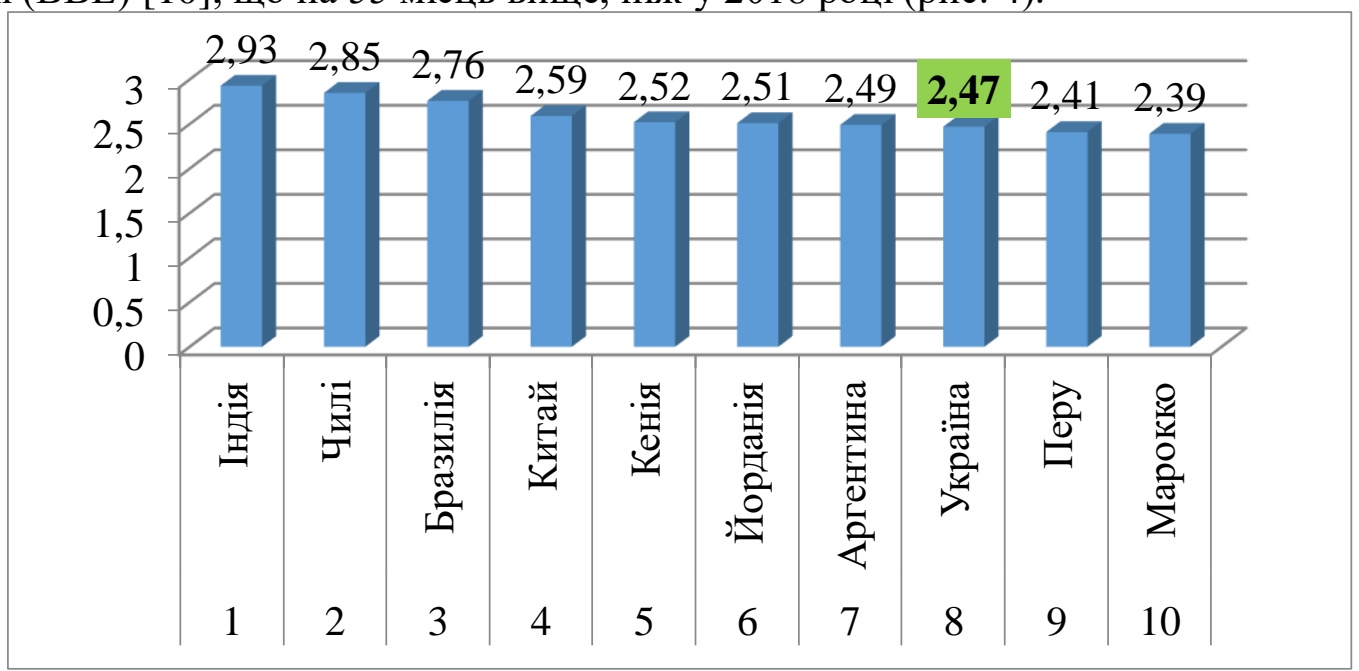

\section{Рисунок 4 - Оцінка привабливості інвестицій у відновлювані види енергії серед країн, які розвиваються, у 2019 р.}

* Складено на підставі щорічного звіту «Climatescope» (http://global-climatescope.org/results) за даними дослідницького агентства «Bloomberg New Energy Finance») 
Комплексна оцінка привабливості інвестицій у відновлювані джерела енергії $\left(\mathrm{R}_{\mathrm{i}}\right.$ вде) розраховувалася за трьома показниками: «Основи» («Fundamentals»), «Можливості» («Opportunities») та «Досвід» («Experience»). Кожний показник оцінювався групою авторитетних експертів у даній галузі 3 урахуванням вагомості $(0,5 ; 0,25$ та 0,25 відповідно). Так, наприклад, для України показник «Fundamentals» склав 3,24; «Opportunities»- 1,24 i «Experience» - 2,17.

Отже, $\mathrm{R}_{\mathrm{i} \text { вде }}=3,24 * 0,5+1,24 * 0,25+2,17 * 0,25=2,47$.

В 2019 році в Україні було перероблено лише 3-4\% побутових відходів та 5\% залишків сільськогосподарської продукції, що розкриває перспективи щодо зростання питомої ваги сміття та відходів АПК в якості сировини для біогазу. За попередньою оцінкою річний вихід біометану з відходів АПК та з полігонів ТПВ може складати 3,2 млрд $\mathbf{m}^{3}$. Вирощування енергетичних культур на непридатних для сільського господарства землях (близько 4 млн. га) додасть ще 3 млрд. м ${ }^{3}$ біометану [13].

32020 року в Україні планують почати функціонувати аукціони для гарантованої закупівлі державою енергії з об'єктів біоенергетики на строк до 20 років, включаючи біогазові електростанції. Термін окупності більшості біогазових установок складає 4-7 років, і тому таке державне стимулювання є суттєвим і економічно вигідним для інвесторів. Біометан можна використовувати у якості палива для автомобілів. А після вироблення біогазу з біомаси, вона стає, біодобривом, яке є екологічно чистим і за своїм складом не поступається хімічним добривам. Ще одним фактором на користь біогазу є те, що біогазові установки (БГУ) не залежать від погоди (сонячних днів, поривів вітру) і можуть забезпечувати безперебійну роботу електростанцій при стабільних поставках сировини. Це дозволяє спрогнозувати інвесторові грошові потоки і потенційні обсяги вироблення біогазу, а також забезпечити стабільність функціонування енергосистеми при підключенні біогазової електростанції до мережі. Утворення електроенергії з біогазу відбувається внаслідок переробки відходів тваринного або рослинного походження, а також побутових відходів. Це сприяє вирішенню двох проблем одночасно: зменшується негативний вплив відходів на навколишнє середовище; скорочуються обсяги утворених і видалених у спеціальні місця відходів. Можливі напрями розвитку біогазових технологій в Україні представлені на рис. 5.

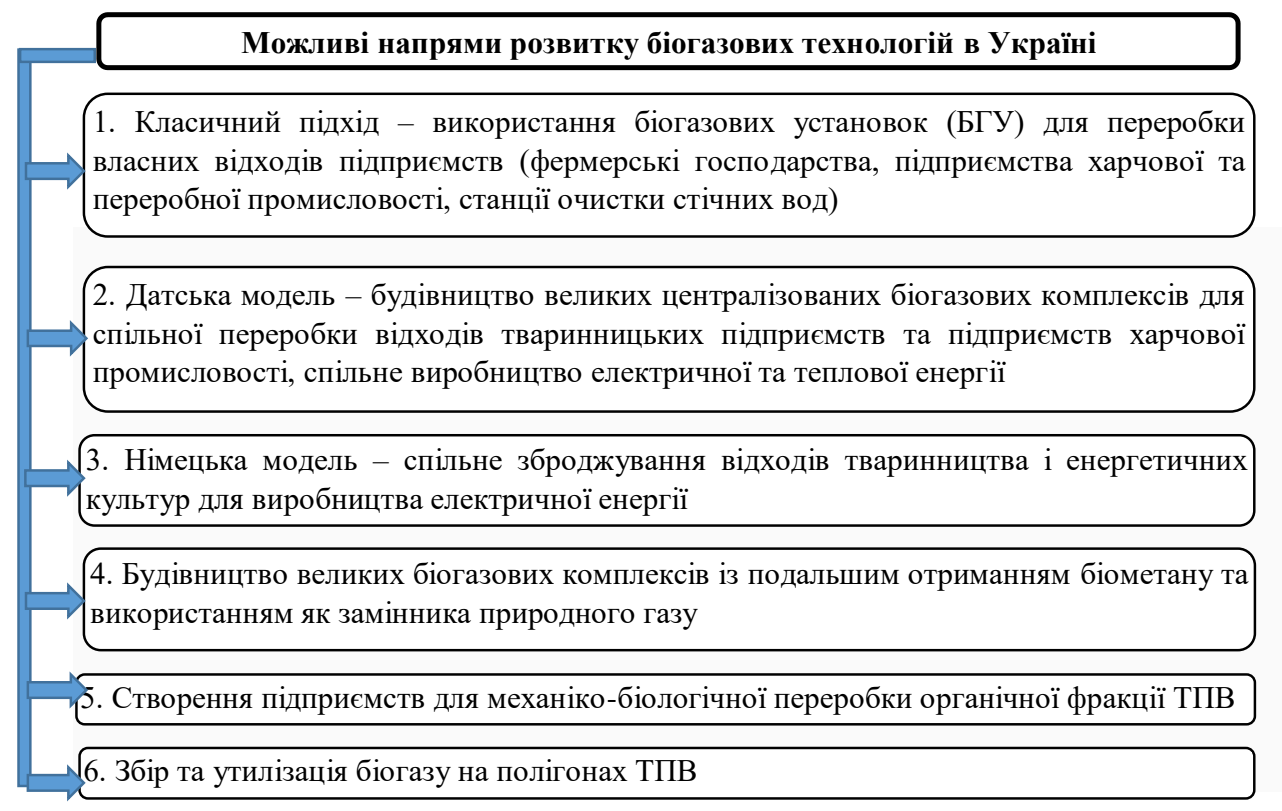

Рисунок 5 - Можливі напрями розвитку біогазових технологій в Україні [11] 
Висока початкова вартість капіталовкладень та доволі тривалий термін окупності (4-8 років) біогазових установок сприяють скороченню кількості фактичних та потенційних інвесторів у ВДЕ. Одним із рішень даної проблеми $є$ створення енергетичного кооперативу - добровільного об'єднання фізичних та/або юридичних осіб на пайовій основі для ведення спільної господарської діяльності у сфері енергоефективності або ВДЕ [16]. Для досягнення поставленої мети (впровадження біогазових установок у регіоні) вважаємо за доцільне об'єднати декілька ферм і домогосподарств Полтавської області Кременчуцького району в енергетичний кооператив (зокрема, приватне сільськогосподарське підприємство «Майбородівське», домогосподарства сел Майбородівка, Мирне, Писарщина, свиноферму у селі Майбородівка), що дасть змогу отримати необхідну кількість гною і оптимізувати виробництво біогазу. До цього інвестиційного проекту можна залучити і АТ «Ізумруд», яке вкладе частину коштів і буде отримувати також теплову та електроенергію від біогазової установки. Річний дохід від продажу електроенергії за зеленим тарифом складе: $2430000 \times 1.21=2,9403$ млн. Свро. Розрахунковий період окупності цього інвестиційного проекту становить 4,6 років, що є досить привабливим для інвесторів, оскільки може гарантувати швидке повернення початкових капіталовкладень.

Окрім прибутку від продажу електроенергії, члени енергетичного кооперативу отримають переваги від використання теплової енергії, яка виробляється без додаткового спалювання біогазу, при охолодженні електричного генератора. Теплова енергія може використовуватися для обігріву приміщень сільського господарства, парників, для сушіння насіння та центрального опалення в селі.

Висновки. У науковій статті отримано такі результати: проаналізовано сучасні методи поводження з відходами; зроблено порівняльний аналіз ринків біогазу країн Європи та України; здійснено оцінку привабливості інвестицій у відновлювані джерела енергії; наведено приклади впровадження проектів 3 добування біогазу з відходів в Україні та за кордоном і їх місце у економіці держави і окремих регіонів; проведено техніко-економічне обгрунтування ефективності будівництва біогазової установки у енергетичному кооперативі Кременчуцького району.

\section{СПИСОК ДЖЕРЕЛ}

1. Эдер Б., Шульц Х., Биогазовые установки: Практическое пособие. 2006. URL: http://zorgbiogas.ru/upload/pdf/Biogas_plants_Practics.pdf

2. Матвєєв Ю., Гелетуха Г. Біогазова станція. Український досвід. Зелена енергетика. 2004. № 1. С. 4-6.

3. Хажмурадов М.А. Установка та технологія по утилізації біогазу. Наука та інновації. 2006. № 4. С. 19.

4. Шафаренко Ю. Кроки держави назустріч інвестиціям. Біоенергетичний день в рамках виставки-форуму "Незалежна теплоенергетика" 12 квітня 2017 p. / Держенергоефективності. URL: http://uabio.org/img/files/Events/pdf/BioDay/1-SAEEShafarenko-steps-of-Ukrainian-government-towards-investments-pdf.

5. Калетнік Г. М., Здирко Н. Г., Фабіянська В. Ю. Біогаз в домогосподарствах запорука енергонезалежності сільських територій України. Економіка. Фінанси. Менеджмент: актуальні питання науки і практики. 2018. № 8. C. 7-22. URL: http://nbuv.gov.ua/UJRN/efmapnp_2018_8_3.

6. Переробка відходів в розвинених країнах світу. URL: http://www.biowatt.com.ua/analitika/pererobka-vidhodiv-v- rozvinenih-krayinah-svitu/.

7. Сайт державної служби статистики в Україні. URL: http://www.ukrstat.gov.ua 
8. Офіційний сайт Енергетика України. URL: http://www.uaenergy.com.ua/index.php/2019/09/musornyiy-gaz/

9. Закон України «Про альтернативні види палива» від 14 січня 2000 р. Відомості Верховної Ради України (ВВР), 2000. № 1391-XIV (ст. 1).

10. Індикатори. Статистика / Міжнародне енергетичне агентство. URL: http://www.iea.

11. Державне агентство з енергоефективності та енергозбереження України. URL: http://saee.gov.ua/en

12. Findeisen C. Biogas - trends on the German and the international market / German Biogas Association. 2019. URL: https: // www.eclareon.com/sites/default/files/clemens findeisen-biogas-_trends_on_the german and international market.pdf

13. Держенергоефективності: інвестиції в альтернативну енергетику: як в Україні заробляють на біогазі. URL: http://itc.ua/news/gosenergoeffektivnosti

14. BioEnergy Farm 2017. URL: http://www.bioenergyfarm.eu/en/

15. Про внесення зміни до Закону України "Про електроенергетику" щодо коефіцієнтів "зеленого" тарифу для електроенергії, виробленої з використанням альтернативних джерел енергії. Відомості Верховної Ради. 2017. № 4. ст.47.

16. Мартинюк А.М., Сакалюк Д.С., Мар'юк О.В., Холодова Н.В. Енергетичні кооперативи: енергонезалежність для громад. Київ: Громадська організація «Екоклуб». $34 \mathrm{c}$. 